\title{
DEMOCRACY IN THE TRAFFIC CIRCULATION PLAN FOR THE CENTRAL AREA OF THE HAGUE, THE NETHERLANDS
}

\author{
SHINJI TSUBOHARA \\ Faculty of Tourism and Community Studies, Atomi University, Japan.
}

\begin{abstract}
The city of Groningen, the Netherlands, introduced the Traffic Circulation Plan (Verkeerscirculatieplan, VCP) in 1977, dividing its inner city into four sectors for cars by enforcing one-way restrictions throughout the inner city. It reduced car traffic in the inner city by half, improving the environment there, and revitalized the city centre. On the other hand, lacking opportunities for the public to participate, the process for introducing the VCP was by no means democratic in terms of participatory democracy, but democratic enough in terms of liberal democracy. In 2009, more than 30 years later, the city of The Hague introduced the Traffic Circulation Plan for the Central Area (Verkeerscirculatieplan Centrumgebied, VCPC), which was based on the sector model like the VCP. The purpose of this article is to re-examine the superiority of liberal democracy over participatory democracy, which was indicated in the case of the VCP, by studying the process for introducing the VCPC in terms of the two types of democracy and the effects of the plan. It turns out that political parties with a majority of seats in the city council took the initiative in introducing the plan while opposition against the plan, which was dominant in public participation, was mostly brushed aside. On the other hand, the plan reduced pollution in the inner city while not undermining the economy there. It can be concluded that the case of the VCPC constitutes another example indicating the superiority of liberal democracy over participatory democracy in realizing the public interest.
\end{abstract}

Keywords: democracy, public participation, The Hague, the Netherlands, traffic circulation plan.

\section{INTRODUCTION}

\subsection{The second traffic circulation plan}

The city of Groningen, the Netherlands, introduced the Traffic Circulation Plan (Verkeerscirculatieplan, VCP) on 19 September 1977, dividing its inner city into four sectors for cars by enforcing one-way restrictions throughout the inner city. It reduced car traffic in the inner city by $47 \%$ while increasing the number of pedestrians in the city centre by $22 \%$, with markets returning. Shopkeepers, who were at first highly critical about the plan, as well as customers have now accepted the plan, with no group demanding its repeal. It can now be said, therefore, that the plan has been conducive to the public interest [1].

On the other hand, lacking opportunities for the public to participate, the process for introducing the VCP was by no means democratic in terms of participatory democracy, where citizens themselves play a decisive role in policy making. The process was, however, democratic enough in terms of another democracy that participationists have tried to replace: liberal democracy, where political parties compete with each other according to distinctive election programmes, and parties winning a majority of the seats implement policies to realize the public interest, even if they face opposition from the public $[1,2]$. The case of the VCP of Groningen, therefore, suggests that liberal democracy is more effective in realizing the public interest than participatory democracy. 
In November 2009, more than 30 years later, the city of The Hague introduced the Traffic Circulation Plan for the Central Area (Verkeerscirculatieplan Centrumgebied, VCPC), which was at first based on the sector model like the VCP of Groningen. This article studies the process for introducing the VCPC in terms of participatory democracy and liberal democracy. It also studies the effects of the plan to see whether it was compatible with the public interest. By doing so, this article aims to re-examine the superiority of liberal democracy over participatory democracy in realizing the public interest, which was indicated in the case of the VCP of Groningen.

\subsection{Methods}

This article mostly relies on written materials. Among others, it examined materials from 2005, when discussion on the VCPC started, through 2011, when various reports about the effects of the VCPC were published, that were found through the City Council's Information System of The Hague (https://denhaag.raadsinformatie.nl/). The keyword used was 'verkeerscirculatieplan'. Discussion at the meetings of the city council and its committees and public hearings is all cited from minutes obtained through this system.

In addition, the author interviewed a former politician of the green party GroenLinks, which argued for making the VCPC first among political parties, in June 2017. The author also received written answers to a list of questions from Dutch Cyclists' Union, whose representatives were continuously involved in the planning process of the VCPC, and the Residents' Organisation Archipelbuurt \& Willemspark, which was one of the most consistent opponents of the VCPC.

\subsection{The Dutch local government}

The Dutch local government adopts the parliamentary system, and councillors are elected through a proportional representational system every 4 years. After the election, political parties with a majority of the seats form the executive branch, the $\mathrm{B} \& \mathrm{~W}$ (college van burgemeester en wethouders). Although burgemeester is generally translated as mayor, the position

Table 1: The chronological table of the VCPC.

\begin{tabular}{l|l}
\hline November 2005 & The B\&W made the VCPC based on the sector model \\
\hline March-April 2006 & Public inspection and information evenings were organized \\
\hline 7 March 2006 & The local election was held \\
\hline July 2006 & The Committee VCP-Nee was established \\
\hline November 2006 & The B\&W decided the second version of the VCPC \\
\hline January 2007 & Public hearings were held \\
\hline February 2007 & The B\&W decided to arrange extended participation \\
\hline March-May 2007 & The extended participation was organized \\
\hline May 2007 & The B\&W decided the final version of the VCPC \\
\hline June 2007 November 2009 & The city council approved the VCPC \\
\hline
\end{tabular}


is neither mayor in the presidential system nor prime minister at the local level. It chairs the $\mathrm{B} \& \mathrm{~W}$ and is appointed by the central government. Each alderman (wethouder) has his or her own work field or portfolio, such as education, finance, urban planning, and traffic.

In the following, this article examines the planning process of the VCPC in chronological order (Table 1). Subsequently, in Section 6, the article also examines the effects of the VCPC.

\section{THE SECTOR MODEL}

\subsection{The most polluted streets in the Netherlands}

Residents along Amsterdamse Veerkade and Stille Veerkade (Veerkades) in the inner city of The Hague had struggled with the 'endless row of stinking cars in front of the door', about 20,000 a day. The National Institute for Public Health and the Environment has installed an air quality monitoring station on Veerkades. Judging from the measurement, the institute declared the streets to be the 'most polluted streets in the Netherlands' in 2005 [3].

In response to the declaration, the city set about making a plan to reconfigure the streets in an attempt to improve air quality there. At the city council's meeting on 10 March 2005, however, the GroenLinks argued for making a traffic circulation plan for the entire inner city including Veerkades so that cars excluded from Veerkades did not shift to other streets in the inner city. At the city council's committees on 1 and 22 June 2005, the GroenLinks again pressed for the traffic circulation plan for the inner city while asking the B\&W the possibility of introducing the 'structure that was chosen in Groningen (a zone system)'. Other political parties also argued for making the traffic circulation plan rather than addressing the problem of Veerkades in an isolated manner.

As a result, the B\&W made the VCPC and decided in November 2005 to further work out the 'Preferred Solution' chosen in the VCPC [4].

\subsection{The Preferred Solution}

According to the definition of the VCPC, which this article follows hereafter, the 'inner city (binnenstad)' is the area within the historical 'canal belt', a part of the 'central area (centrumgebied)', which is bordered by CentrumRing (Fig. 1).

The plan comes up with five 'variants', such as 'Sectors', 'Ring', and 'Maximum', for the traffic scheme of the central area. Comparison of these variants reveals that 'the variant sectors scores more positively than the other variants almost across the board and also does not cause any strong deterioration'. This variant proposes dividing the inner city into three sectors, instead of four in Groningen, by cutting three routes for cars as well as making Spui car-free. Cars cannot move between these sectors; they can reach their destinations, including parking garages, in the inner city through loops from CentrumRing.

Using the variant sectors as a 'basis', the VCPC chooses the optimal traffic circulation, the Preferred Solution (Figs. 1 and 2). With this circulation, there would be 'no longer any through traffic in the inner city', whereas traffic on CentrumRing would increase 'about $16 \%$ on average', and particularly Vaillantlaan, a part of CentrumRing, would see an increase of traffic by $32 \%$.

Given these findings, the VCPC argues for measures to streamline CentrumRing. These include reconfiguring intersections on Vaillantlaan, optimizing traffic lights on and near CentrumRing, and replacing the railway underpass De Put, a project by the ProRail that would make the underpass wider, higher, and brighter. 


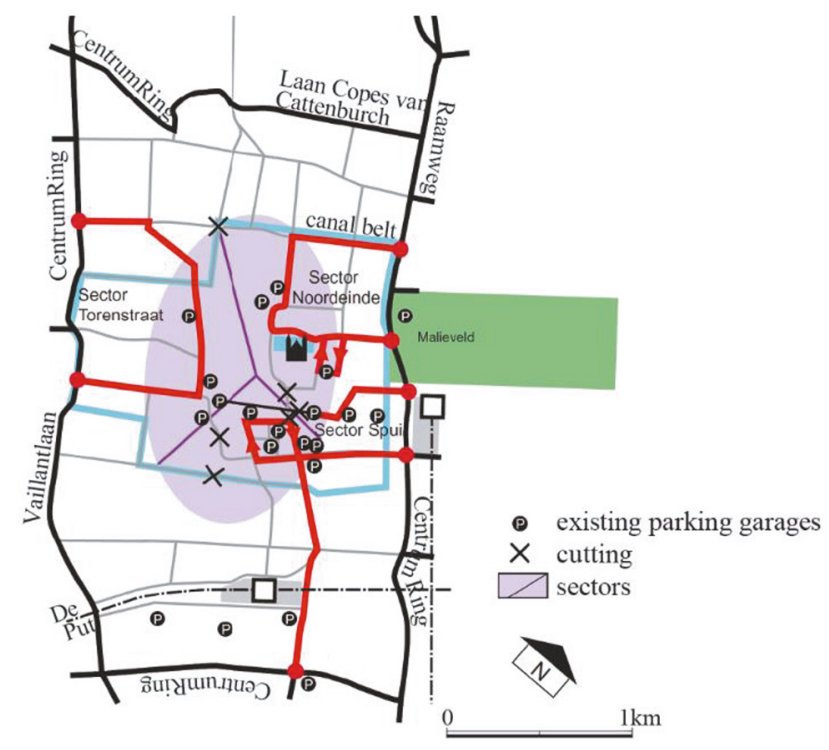

Figure 1: CentrumRing and the Preferred Solution [5].

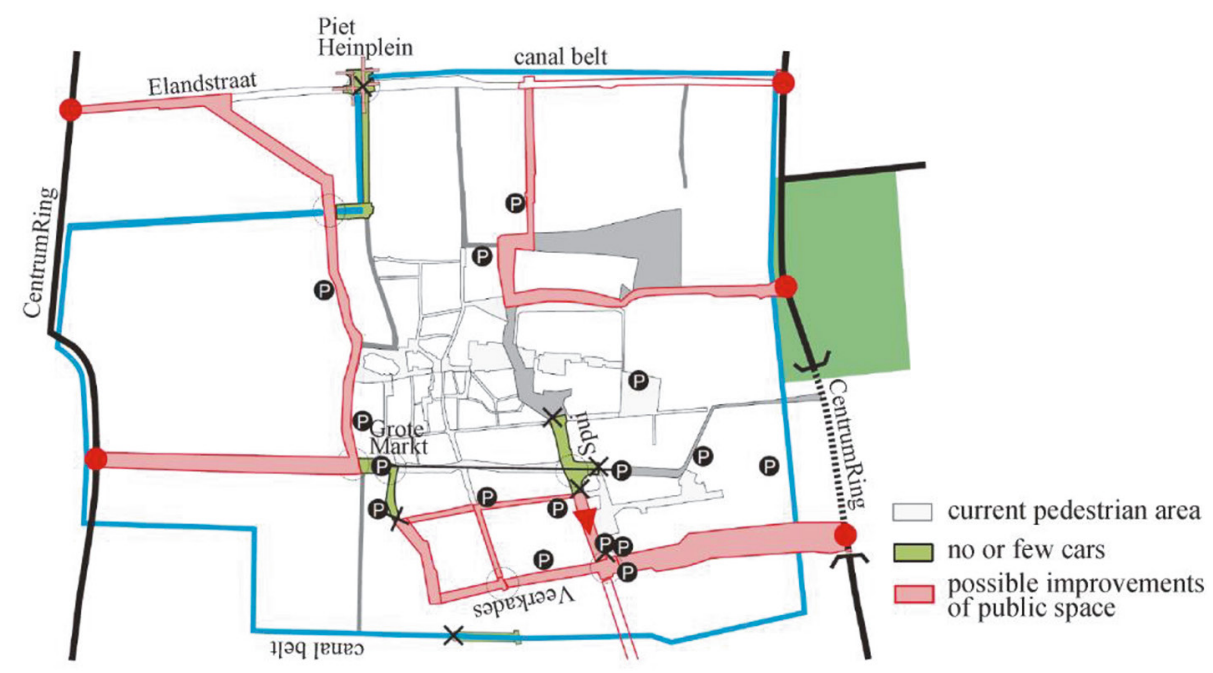

Figure 2: The Preferred Solution for the inner city [5].

Finally, the VCPC presents the schedule. The construction work at De Put further reduces the capacity of CentrumRing, so it is crucial to complete this project before introducing the VCPC. Because the project at De Put is scheduled to be completed at the end of 2008, 'the spring of 2009 is the most obvious time to implement this Traffic Circulation Plan', the VCPC concludes [5]. 


\section{THE COALITION AGREEMENT}

\subsection{The first participation}

The VCPC was made available for public inspection from 6 March to 28 April 2006, during which citizens could submit their opinions by letter or e-mail. During this period, the city also organized four 'information evenings' in and around the central area.

In total, more than 160 written opinions were submitted. The 'most important topic' raised was the 'economic position of the inner city', which would not benefit from the VCPC, according to submitted opinions. 'Another topic' was 'the shift of traffic and accompanying air pollution from the central area to CentrumRing'.

Opinions voiced at the information evenings were mostly the same as the written opinions, pointing out the VCPC's negative effects on economy and air quality [6].

\subsection{Election programmes}

One day after the public inspection started, on 7 March 2006, local elections were held. As is usually the case with Dutch local elections, the local division of each political party in The Hague published an election programme, a party policy for the city, before the election. These election programmes included traffic policies related to the VCPC.

The liberal party VVD, the largest party before the election, stands for the 'free choice of means of transport' in its election programme. 'Various sorts of high-quality transport, therefore, must exist side by side', according to the party [7].

In contrast, the election programme of the labour party PvdA, the second largest party, does not accept the free choice of means of transport: 'the growth of car mobility must be restrained through charges, investment in public transport, and the promotion of the use of bicycles'. For the inner city, the party advocates a 'car-restricted inner city to realise a substantial reduction of emissions of particulate matter and a more attractive atmosphere to stay' [8].

In its election programme, the GroenLinks also stands for '[1]ess cars, more public transport, and more bicycles'. The party, again like the PvdA, advocates a 'car-restricted inner city'. Moreover, the party wants to 'make the inner city car-free in the long term' [9].

\subsection{The coalition agreement}

The result of the local election in The Hague followed the nationwide results: a major victory for the PvdA and the socialist party SP and a loss for the VVD and Christian democratic party CDA. The PvdA of The Hague increased its seats from 10 to 15 of 45 in total, supplanting the VVD, which lost one seat to win ten seats, as the largest party. The CDA won five seats, losing two seats of seven seats. The SP doubled its seats, from two to four. With the GroenLinks maintaining previous three seats, a significantly left-leaning city council came into being.

This new distribution of seats in the city council was reflected in the makeup of the new $\mathrm{B} \& \mathrm{~W}$ and its coalition agreement. Replacing the CDA, the GroenLinks joined the B\&W with the PvdA and VVD. The GroenLinks wanted to just implement the VCPC while the PvdA also wanted to implement it fully. As a result, the coalition agreement states, 'We are going to implement the VCP[C] entirely' [10], which was a minus point for the VVD. Therefore, 
although public participation was not yet completed, the B\&W had already made a choice of the Preferred Solution.

In protest against the coalition agreement, the Committee VCP-Nee was established in July 2006. It was joined by more than 30 organizations, consisting of residents' organizations in the north of the central area and around the northern section of CentrumRing and business organizations including the Chamber of Commerce. Its objections against the VCPC included that the plan would 'make shopping areas around the centre very poorly accessible', that it would 'shift problems to residents along CentrumRing', and that it had 'no support among residents and businesses within CentrumRing' [11].

\subsection{No reason to change}

The B\&W decided the second version of the VCPC and submitted it to the city council in November 2006. The second version adopts the Preferred Solution, that is, the sector model, of the original version as it is, proposing the same three sectors.

It presents the 'Reactions' from participants as shown before, admitting that there were serious objections and concerns about the original version. Those reactions, however, 'have given no reason to change the standpoint of the $\mathrm{B} \& \mathrm{~W}$ on the introduction of a car-restricted inner city by means of the' VCPC. According to the schedule, in the 'first quarter of 2009', the VCPC is introduced and 'a car-restricted inner city becomes a reality' [6].

\section{THE EXTENDED PARTICIPATION}

\subsection{Public hearings}

The city council's committee organized public hearings on the VCPC twice on 10 and 30 January 2007. It invited about 50 citizens who had been involved in discussion about the VCPC, including the representatives of residents' and business organizations.

At these public hearings, the proposed VCPC could garner little support, with both businesses and residents severely criticizing the plan. Because the plan would significantly undermine the accessibility of customers by car and the supply of goods, it would be 'a sort of heart attack', a 'deathblow', or 'disastrous' for businesses. In residential neighbourhoods, because of the plan, 'accidents' would happen, and 'environmental burden would structurally increase', with a result of bringing 'a sort of second Veerkade' into being. While opposing the VCPC, the representative of the VCP-Nee mentioned an alternative called the VCP2 (Fig. 3), proposed by a freelance journalist. The VCP2 argued for creating one-way CityRing, a much smaller circular route than CentrumRing, by adjusting the existing parking route. 'This plan particularly appealed to' the VCP-Nee, according to the representative.

On the other hand, residents along Veerkades themselves were rather silent in supporting the VCPC, while other participants repeatedly indicated that the VCPC tried to improve the environment of Veerkades at the expense of the environment of other streets.

\subsection{The extended participation}

After these public hearings, the VCP-Nee proposed that a 'committee of wise men' should be established to study whether there was an alternative to the VCPC. The VVD, which had consistently opposed the VCPC, supported this idea, but the other two government parties, 


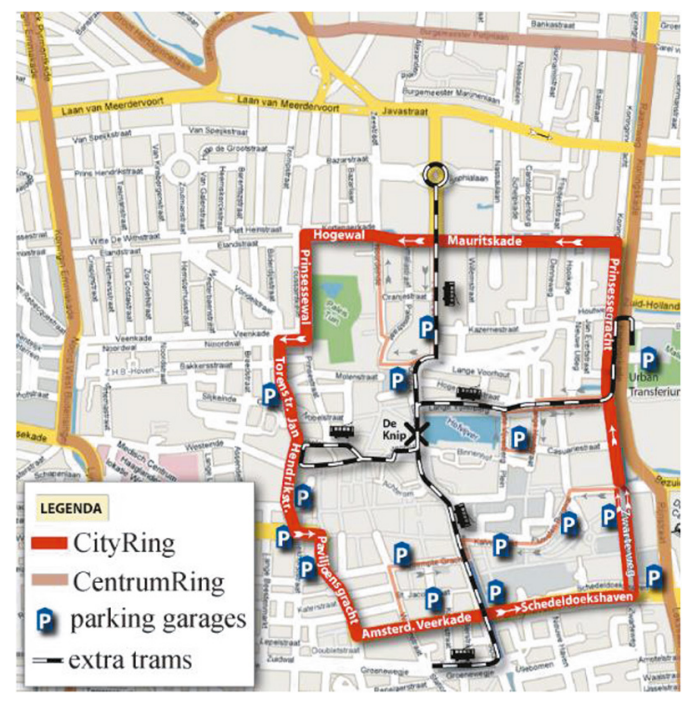

Figure 3: CityRing [12].

the PvdA and GroenLinks, rejected it. Because the VVD threatened to step out of the B\&W, the three parties negotiated a solution to the conflict. In February 2007, they decided to continue their coalition on the following condition.

They should start 'extended participation' with 'key figures', namely, those about 50 citizens who participated in the public hearings in January. During the extended participation, the following three opportunities were to be provided for the public to participate:

- Workshop VCP[C] (8:00-14:00, Monday, 19 March)

- Results Workshop (19:30-22:30, Wednesday, 28 March)

- Presentation VCP[C] and variants (19:30-22:30, Wednesday, 2 May)

Thereafter, the B\&W should decide the adjusted proposal of the VCPC for the city council, which should decide it on 14 June 2007 [13]. Therefore, the deadline was already precisely fixed.

\subsection{The results of the extended participation}

\subsubsection{Workshop VCP[C] on 19 March}

The first workshop consisted of two rounds.

In the first round, the key figures were divided into four groups, according to four themes: air quality, pedestrians and slow traffic, excluding through traffic, and local traffic. They were asked to put forward ideas about 'solutions with regard to the theme and the VCP[C]'. As a result, each of the groups advanced many, wide-ranging ideas such as 'Plan London, congestion charging', 'More expensive parking', and 'Free public transport'.

In the second round, four groups were again formed, but with a different makeup from the first round. They shared all the ideas produced in the first round, and each group was asked to 'draw one or two scenarios from the ideas'. In fact, each group made two or three 
scenarios, which were actually not alternatives but different sets of ideas that were not mutually exclusive. After each group presented these scenarios in the plenary session and the present aldermen made some comments about them, however, one of the aldermen concluded the workshop by saying that he saw three alternatives or "variants (scenarios) come forward this morning'. The three variants he mentioned were as follows:

1. $\mathrm{VCP}[\mathrm{C}]$ with a package of measures

2. The small CentrumRing

3. Only curbing traffic, not excluding [14]

Therefore, variants were already presented at the first workshop, although their contents were not yet worked out.

\subsubsection{Results workshop on 28 March}

At the second workshop, the alderman of traffic first presented a 'supportive policy', measures for public transport and bicycles that could 'be implemented alongside all the three variants'.

Then, he explained three variants one by one. Among them, Variant 2, 'CityRing', like the VCP2, proposes creating a 'good, flowing route for car traffic close to the inner city and parking garages'.

After a break, participants, the key figures, were given an opportunity to react to the supportive policy and those three variants. A participant, however, asked how these variants were chosen at all because 'the participants d[id] not recognise the previous meeting in them'.

At the end of the meeting, the alderman found 'the greatest common denominator from the room': 'People accepted the supportive policy, variants 1 and 3, and variant 2 in an adjusted form' [15]. To be precise, they just accepted, tacitly, that the city would calculate the effects of the supportive policy and the variants.

\subsubsection{Presentation VCP[C] and variants}

On 1 May, one day before the third meeting, the alderman of traffic sent a letter to the city council's committee reporting the results of the calculation. Among the three variants, the variant CityRing would 'improve the air quality nearly everywhere in the centre' while it would cost least, according to the results. At the end of the letter, the alderman specified the scheduled date of decision by the B\&W on the VCPC: 15 May. Therefore, only 2 weeks were left after the third and last meeting with the key figures [16].

At the third meeting on 2 May, the alderman of traffic first explained the three variants and their effects. The B\&W, however, did not intend to 'make a choice from the three variants', according to him; the variants were nothing but a 'playing field for the possible measures'.

On the part of participants, given the favourable effects of the variant CityRing, not only the representative of the VCP-Nee but also other participants supported this variant. No one expressly supported the other two variants.

The next day, on 3 May, three meetings were held simultaneously for residents and businesses in the inner city, the south, and the north of the inner city. A different alderman attended each of these meetings, presenting the variants and their effects.

Participants in the inner city, who gathered at the city hall, almost unanimously supported the variant CityRing as the 'best option', while the support of participants in the south was divided between the three variants. 
On the other hand, the meeting in the north was much more contentious, with the three variants themselves hardly discussed. Participants were in unison anxious that car traffic and accompanying air pollution would shift to the northern section of CentrumRing, particularly Laan Copes van Cattenburch, from Veerkades. In the alderman's view, however, the 'task of the B\&W' was to 'take a balanced decision', according to which problems 'must be shifted and weighted in an acceptable manner' [17]. That is why he openly admitted that some areas must accept the deterioration of their environment to some extent to relieve other areas suffering from serious air pollution.

\section{DECISION}

\subsection{The proposal for the city council}

As scheduled, the B\&W decided the final version of the VCPC, the proposal for the city council, on 15 May 2007. The proposal is not so different from the second version. It does give up placing a cutting on Piet Heinplein, instead introducing a westward one-way restriction on Elandstraat. It maintains cuttings at other places, however, making Spui and Grote Markt car-free.

The proposal again relates the date of introducing the VCPC with the project at De Put: the VCPC is introduced 'after the new underpass is put into use' [18]. The project was meanwhile delayed, scheduled to be completed in November 2009.

After the B\&W's decision on the proposal, the city published reports studying the effects of the proposal on air quality and economy in June. According to the reports, 'the significant violations of norms for $\mathrm{NO}_{2}$ and $\mathrm{PM}_{10}$ on Veerkades no longer occur' with the proposal. On the other hand, 'on some parts of Vaillantlaan', the norm for $\mathrm{NO}_{2}$ is exceeded in 2010 without the proposal, or in the 'autonomous situation', and 'somewhat further exceeded' with the proposal. In the central area as a whole, the proposal reduces the $\mu$ g-residents - an index taking into account not only to what extent the air quality exceeds the environmental standard but also how many people live in the air - by $5 \%$ and $8 \%$ for $\mathrm{PM}_{10}$ and $\mathrm{NO}_{2}$, respectively, compared with the autonomous situation [19].

The effects of the proposal on economy are 'limited in general', but they are 'neutral to slightly positive for the centre as a whole' [20].

\subsection{Decision on the VCPC}

The proposal was presented to the city council on 14 June, again as scheduled.

Before discussion by councillors, 13 citizens took the opportunity to voice their opinion about the proposal. While the representative of the Environmental Centre of The Hague supported the proposal as the 'first step in the direction of a cleaner and more sustainable mobility policy', all the other citizens opposed it, criticizing the extended participation as a 'sham'.

During subsequent discussion by councillors, political parties opposing the proposal repeated the above criticisms. They could not find those three variants in the proposal, wondering, 'What was done with the participation at all?'. The proposal was nothing more than the 'original plan with a cutting less', which was 'purely shifting the problems', without solving them.

Removing the cutting on Piet Heinplein, however, was enough to change the opinions of the VVD and CDA, both of which had consistently opposed the VCPC. The 'proposed 
adjustment' to Piet Heinplein solved the problem of accessibility in the original VCPC, according to them.

For the GroenLinks and PvdA, the proposal could not only solve the air pollution on Veerkades without shifting too much pollution to other neighbourhoods; it could also contribute toward creating a car-restricted inner city, an idea advocated by both parties in their election programmes. Citing the report on air quality published just before, the GroenLinks argued, 'more people assume a little bit more burden'. 'Overlooking the whole and looking at the advantages and disadvantages', 'the disadvantages do not outweigh the advantages' of the proposal, the PvdA said. Moreover, thanks to the proposal, 'the place for cyclists and pedestrians would become somewhat larger' and the 'atmosphere to stay' 'would become much better'.

After the alderman of traffic defended the proposal, saying it would create 'a more equal landscape in The Hague with regard to air quality', the proposal was put to a vote. It was approved by 34 to 11, with the PvdA, GroenLinks, VVD, and CDA supporting it.

\section{EFFECTS}

\subsection{The VCPC introduction}

In June 2009, the city started to install automatic bollards on streets in the inner city, which were intended to make Spui and Grote Markt car-free while preventing car traffic from shifting to other streets. With the 9 September 2009 issue of the city bulletin, titled 'Around the inner city: Important news over traffic', the city launched a public relations campaign about the VCPC.

On 18 November 2009, the project at De Put was completed, and immediately as planned, on 20 November, the city officially introduced the VCPC, with the automatic bollards raised. Cars are still allowed to enter the car-restricted area blocked by the bollards from 5:00 to 11:30 on weekdays and from 6:00 to 11:30 on weekends, but only for loading and unloading. For other times and purposes, only those granted exemption, such as ambulances and residents in the inner city, are allowed to enter the area by car [21].

\subsection{Traffic}

Although the VCPC immediately 'got rid of the endless row of stinking cars in front of the door' [3] on Veerkades, traffic increased on some sections of CentrumRing, particularly on Vaillantlaan, which saw an increase of 53\% from 2008 to 2010. Northern sections of CentrumRing, where residents had most strongly opposed the VCPC, however, did not see a significant increase in traffic, even experiencing a decrease on some sections [22].

\subsection{Air quality}

For one year in 2008 , the city measured the concentrations of $\mathrm{NO}_{2}$ at 23 points in the central area 'with heavy traffic or where a large increase or decrease [wa]s expected' in traffic [23]. In 2010, it conducted the same measurements, comparing the annual average concentrations in 2008 and 2010. It turned out that the air quality on Veerkades was significantly improved: the concentrations of $\mathrm{NO}_{2}$ along Stille Veerkade decreased from $49.0 \mu \mathrm{g} / \mathrm{m}^{3}$ to $42.5 \mu \mathrm{g} / \mathrm{m}^{3}$. Among the other 22 points, only five points experienced a decrease in $\mathrm{NO}_{2}$, while 16 points 
experienced an increase, with one point seeing no change. All these changes, however, were not so significant as the change along Stille Veerkade. In addition, among those points experiencing an increase, only Raamweg and Vaillantlaan, both a part of CentrumRing, registered values higher than the 2008 value of Stille Veerkade, $49.0 \mu \mathrm{g} / \mathrm{m}^{3}$, in 2010 [22].

The consultancy firm DGMR, commissioned by the city, calculated the concentrations of $\mathrm{NO}_{2}$ for all the streets in the central area for three situations: the autonomous situation without the VCPC, the predicted situation with the VCPC, and the realized situation with the VCPC. The parameters used for the calculation included traffic volume, driving speeds, street profiles, and weather conditions. It then calculated the environmental burden as expressed by the index $\mu$ g-residents for CentrumRing, Veerkades, and the rest of the central area. It turned out that the environmental burden on Veerkades decreased $83 \%$ in the realized situation compared with the autonomous situation. Even on CentrumRing, the environmental burden decreased $-13 \%$ smaller in the realized situation. For the whole central area, the VCPC reduced the environmental burden by $31 \%$ compared with the autonomous situation, much better than the value of $8 \%$ predicted just before the city council decided the VCPC [23].

\subsection{Economy}

According to a study on the economic effects of the VCPC, the Central The Hague, which mostly corresponds with the inner city, experienced a significant increase of vacant retail space, $61.2 \%$, from 2009 to 2011. The study, however, compares the Central The Hague with the central shopping areas of the four largest cities in the Netherlands, or G4 - Amsterdam, Rotterdam, The Hague, and Utrecht - and The Hague Region. It turns out that G4 and The Hague Region experienced an even larger increase of vacant retail space: $78.0 \%$ and $86.5 \%$, respectively. The number of passers-by in the Central The Hague on an average Saturday decreased 3\% from 2008 to 2010 . This was again not so bad compared with the other G4 cities and The Hague Region. For example, the Central Utrecht experienced a 5\% decrease of passers-by and the Central Rotterdam experienced an 18\% decrease [24].

Although it is difficult to prove that the VCPC alleviated the impact of the 2008 global financial crisis, the plan was by no means a 'deathblow' or 'disastrous' for the economy of the central area as alleged before its introduction.

\section{CONCLUSIONS}

The VCPC has certainly not solved all the traffic problems in the central area of The Hague. For example, the concentrations of $\mathrm{NO}_{2}$ on some streets were recently reported to far exceed the European standard, and an environmental group, at least partly, blamed this on the VCPC [25]. However, 'friends and foes agree that the VCP[C] has also done many good things for the inner city' [3]. As a result, those who are trying to solve current traffic problems in the central area, including those who strongly opposed the VCPC, do not argue for repealing the plan to solve the problems, instead asking for closing their own streets to through traffic or expanding the environmental zone in the inner city, which trucks with old engines are banned from entering. The VCPC did improve the air quality of the central area as a whole while solving the pollution problem on Veerkades, and the public has mostly accepted the plan. Therefore, it could be concluded that the VCPC was a successful project, consistent with the public interest, as is the case with the VCP of Groningen.

On the other hand, the VCPC was not the product of participatory democracy but the product of liberal democracy. If participatory democracy had been pursued, the result would have 
been no VCPC or the CityRing, both of which did not solve the problem on Veerkades. At the public hearings on 30 January 2007, a member of the VCP-Nee said that the problem should not be an 'either/or question', namely, whether the problem on Veerkades was solved or the environment on other streets was kept intact. In fact, this was an either/or question: other streets must accept a somewhat increase in traffic to solve the problem on Veerkades, at least until traffic as a whole decreases. As a PvdA councillor said at the city council's meeting on 14 June 2006, 'no plan can be made that everyone will support with great enthusiasm'. Residents on Veerkades themselves, however, could not ask residents on other streets to sacrifice their environment at participatory opportunities. Therefore, 'We', namely, politicians, 'must make a choice', in accordance with liberal democracy. The VCPC was criticized for being the result of negotiations between government parties and an 'extremely political plan' [26]. Because of being political, however, the VCPC has realized the public interest.

That is why the VCPC of The Hague, like the VCP of Groningen, suggests the superiority of liberal democracy over participatory democracy in realizing the public interest.

\section{REFERENCES}

[1] Tsubohara, S., Democracy through political parties and public participation: the case of the planning history of Groningen, the Netherlands. Dissertation, University of Groningen: Groningen, pp. 59-83, 2010.

[2] Sartori, G., The Theory of Democracy Revisited, Chatham House: Chatham, New Jersey, 1987.

[3] AD, Pollers houden binnenstad Den Haag al 5 jaar autoluw, available at http://www. ad.nl/ad/nl/1040/Den-Haag/article/detail/3794541/2014/11/20/Pollers-houden-binnenstad-Den-Haag-al-5-jaar-autoluw.dhtml, 2014 (accessed 28 April 2016).

[4] Gemeente Den Haag, Verkeerscirculatieplan Centrumgebied, available at https://denhaag.raadsinformatie.nl/document/3333820/1/RIS133650, 2005 (accessed 21 December 2016).

[5] Gemeente Den Haag, Verkeerscirculatieplan Centrumgebied Den Haag, pp. 7-57, 2005.

[6] Gemeente Den Haag, Verkeerscirculatieplan Centrumgebied: Anders Rijden voor een Betere Binnenstad, 2006.

[7] VVD Afdeling Den Haag, Verkiezingsprogramma VVD Den Haag: Trots op Den Haag, p. 14, 2006.

[8] PvdA Den Haag, Verkiezingsprogramma: Solidair, Betrokken, Duurzaam, p. 6, 2006.

[9] GroenLinks Den Haag, Verkiezingsprogramma: Natuurlijk Beter, pp. 17, 21, 2006.

[10] PvdA, VVD, GroenLinks Den Haag, Coalitieakkoord 2006-2010: MeeDoen, p. 23, 2006.

[11] Comité VCP NEE, available at http://www.bof-denhaag.nl/documenten/foldervcp_nee. pdf, 2006 (accessed 3 May 2016).

[12] Bekker, E., VCP-twee, available at http://www.layout.nl/in_de_media/2007_01_12_hn/ vcp-twee.pdf, 2007 (accessed 20 July 2017).

[13] Gemeente Den Haag, Uitnodiging workshop VCP 19 maart 2007, available at https:// denhaag.raadsinformatie.nl/document/3373846/1\#search=\%22verkeerscirculatiepl an\%22, 2007 (accessed 27 January 2017).

[14] Gemeente Den Haag, Verslag workshop sleutelfiguren: Maandag 19 maart 2007, pp. 3-8, 2007. 
[15] Gemeente Den Haag, Verslag presentatie aan sleutelfiguren: Woensdag 28 maart 2007, pp. 1-10, 2007.

[16] Gemeente Den Haag, Effecten varianten verlengde inspraak Verkeerscirculatieplan Centrumgebied, available at http://www.denhaag.nl/web/file?uuid=1f5c9be07a6f-4536-9712-ad55f5013597\&owner=bfadc11e-971e-465e-b613-5da689f27 cd0\&contentid=20119, 2007 (accessed 2 May 2016).

[17] Gemeente Den Haag, Presentatie van de effecten van de drie varianten, 2007.

[18] Gemeente Den Haag, Voorstel van het college inzake Verkeerscirculatieplan Centrumgebied Den Haag, available at http://www.denhaag.nl/home/bewoners/gemeente/ document/Voorstel-van-het-college-inzake-Verkeerscirculatieplan-CentrumgebiedDen-Haag.htm, 2007 (accessed 21 April 2016).

[19] DGMR, Verkeerscirculatieplan Centrumgebied Den Haag: Luchtkwaliteit, Gemeente Den Haag, p. 25, 2007.

[20] Goudappel Coffeng, Economische Effecten Verkeerscirculatieplan Centrumgebied Den Haag: Eindrapport, Gemeente Den Haag, p. 12, 2007.

[21] Gemeente Den Haag, Toegang bestemmingsverkeer voetgangersgebieden Den Haag, available at https://www.denhaag.nl/nl/algemeen/toegang-bestemmingsverkeer-voetgangersgebieden-den-haag.htm, 2014 (accessed 24 December 2017).

[22] Tabula Rasa, Effectmeting Verkeerscirculatieplan 2011, Gemeente Den Haag, pp. 25, 57, 2011.

[23] DGMR, Evaluatie Luchtkwaliteit Verkeerscirculatieplan Den Haag, Gemeente Den Haag, pp. 12-28, 2011.

[24] Locatus, Economische Ontwikkeling Binnenstad Den Haag: Effectmeting, Gemeente Den Haag, pp. 56, 65, 2011.

[25] dichtbij, Haagse Hoefkade meest ongezonde straat in Den Haag: kuchende bewoners overhandigen rapport, available at http://www.dichtbij.nl/den-haag/regionaal-nieuws/ artikel/4250909/haagse-hoefkade-meest-ongezonde-straat-in-den-haag-kuchende-bewoners-overhandige, 2016 (accessed 6 June 2017).

[26] Andersson Elffers Felix, De Kwaliteit van Inspraak en Samenspraak in Den Haag: Eindrapport, Gemeente Den Haag, p. 64, 2009. 